Sharov S. V., PhD (Candidate of Pedagogical Sciences), Associate Professor, Department of Informatics and Cybernetics Bohdan Khmelnytsky Melitopol State Pedagogical University

\author{
Karnachova S. M., \\ Student, \\ Bohdan Khmelnytsky Melitopol State Pedagogical University
}

\title{
DEVELOPING CIVIC COMPETENCE THROUGH THE ART OF THE WORD (BASED ON K. GORDIENKO'S LITERARY WORKS)
}

Summary. At present, one can notice a growing interest in civic education, due to significant social changes in Ukraine and its integration into European space. Civic competence is an important condition for the existence of an intercultural and democratic society, in which every citizen actively expresses his attitude to the various social, political and national processes of the present. The study of works of art and literature is one of the most promising and effective means of forming civic competence. It will give an opportunity for a person to learn how to analyze, contrast and compare images, objects and phenomena, to form their own opinion and active civil position. The paper is aimed at an characterization of the word art means for civic competence fostering based on K. Gordienko's literary contribution, at the report on development and use of electronic tools for educational assignment with a view of mastering better the writer's works. Methods of analysis, synthesis and systematization were used to achieve the goal, which allowed to determine the place and role of K. Gordienko's development in the historical-literary process; the study of psychological changes, reflected in behavior and experiences of writer's main characters, called for applying the methods of research psychology; the structural-typological method was used for the analysis and comparison of the author's literary texts; the systematic approach to the examining of the writer's literary heritage made it possible to actualize the systemmaking factors of his poetics. It was revealed that one's civil competence involves the active, conscious, and responsible attitude to social and civic processes directed at the development of the state. Developing civic culture through the art of the word can foster a true patriot of Ukraine, which is currently extremely important and necessary. The comprehensive analysis of the writer's literary heritage gave an opportunity to clarify the role and place of the writer and his works in the context of literary and aesthetic aspirations of Ukrainian literature of XX century and to determine his national-patriotic views. In order to improve the quality of the civil culture formation process there was developed an electronic tool for educational purposes, which contains the theoretical material, literary work, epistolary, photo gallery and video materials about K. Gordienko.

Key words: civic competence, patriotism, the art of the word, fiction, electronic teaching tools.
Problem statement. Today, significant social changes in Ukraine and its integration into European space have determined a growing interest in civic education. Formation of civil competence of the person is relevant taking into consideration conditions of competence approach in education and the need to prepare a young generation capable to take an active part in the life of a democratic society. Civic competence formation can be found in numerous scientific works of the researchers. This issue was studied by I. Ovcharuk, who considers educational measures of patriotic direction to be effective means in civic competence fostering. O. Pometun identified the components of civic competence, which she believes to be a key competence of the younger generation. 0 . Barau investigated the use of didactic tools for the implementation of civic education in educational process [1].

Among foreign scientists, it is possible to allocate the works of J. Prasans, who advocated an interdisciplinary approach and introduced issues of civic education to secondary schools in the book [12]. Analysis of the development of civic competence was carried out by scientists J. Schwartz and D. Barone [14]. M. Głowinski was engaged in the search for civic education in national-patriotic direction in his philosophical works [10]. N. Stepanova raised the issues of civic competence, where she emphasizes the person's socialization by means of the art of the word. The same aspirations had K. Chorna, whose works are devoted to main priorities of fostering the patriot through the word.

The purpose of the article. The paper is aimed at an characterization of the art of the word means for civic competence fostering based on K. Gordienko's literary contribution, it has also the goal to report about the development and the use of electronic tools for educational assignment with a view of mastering better the writer's works.

Research. Methods of analysis, synthesis and systematization were used to achieve the goal, which allowed to determine the place and role of K. Gordienko's development in the historical-literary process; the study of psychological changes, reflected in the behavior and experiences of the main characters of the writer, called for applying the methods of research psychology; the structural- 
typological method was used for the analysis and comparison of the author's literary texts; the systematic approach to the examining of the writer's literary heritage made it possible to actualize the system-making factors of his poetics.

Different researches interpret civic competence as a set of features of an individual to have their own opinion and be responsible for it [6, p. 231], to implement their own rights and duties, actively to participate in social processes [8, p. 128]; to protect the interests of the citizen of the country. His includes not only civic knowledge, but also civic skills and dispositions. Civic culture implies the possession of knowledge and skills that cover: understanding national, European and universal values; knowledge about civil society and the process of making public decisions; the orientation in the problems of modern social life in Ukraine and abroad; awareness of personal responsibility and sense of duty; active and responsible position of a citizen of the country.

Taking into consideration the fact that Ukraine is a state where people of different nationalities live, the researches done by V. Pang, G. Gay, W. Stanley are appropriate to study. The scientists believe that ideas of universal unity of all citizens of the state who have the same rights and responsibilities characteristic of a democratic society provide the basis of civic competence of a member of multicultural society [12, p. 321].

O. Pometun considers civic competence to be manifestation of the formed citizenship of the individual, who is capable to actively and responsibly use civil rights and duties with the goal of developing a democratic society. The researcher identifies three components of civic competence, namely: axiological, active, procedure [3, p. 67]. Having an active and responsible position in the society, the younger generation will be able to protect their family and itself from danger.

As noted by 0 . Shestopalyuk, civic competence cannot be fostered only when studying the subjects of socio-political cycle, because it provides the development of some key competences: research; communicative; training; competence of social choice and social action [9, p. 34]. We consider one's acquaintance with works of art and literature to be the most promising and effective means of civic competence fostering, as due to them a person can learn to analyze, compare images and phenomena, defend their own opinions, etc. In this aspect we agree with V. Panchenko, who believes that one should not forget about national and universal values, justice, honesty, respect for human dignity, national history, culture and traditions when reading literature works [5, p. 159].

Civic competence has a national-Patriotic basis, because it assumes a citizen's active position in a particular country that has its own laws, traditions, internal and external policies. Thus, educational institutions have great responsibility as they provide the process of forming civic competence based on democratic principles and the principle of respect for the individual. In the case of secondary school its education should initially be directed on fostering an active citizen who is able to think about social problems and not to be indifferent to them. When talking about higher school future specialist, in particular the teacher of the Ukrainian language and literature, they should read the artistic texts, get acquainted with contemporary literature, be proud of the classics and speak their native language while shaping their own image [4, p. 123].

It should be noted that there has been a significant rethinking of ideas as to the development of the history and literature of the twentieth century, which converged with life, and expanded the labor, social and spiritual spheres of a man. A significant feature of the vast majority of writers of the twentieth century is their ability to closely observe the world and to portray it in realistic dimensions, to undertake philosophical generalizations about man and society. By contemplating past events and peculiarities of people's lives in a new way, it is possible to apply particular artistic images and stereotypes of behavior in modern realities. Thinking in a new way about those events and peculiarities of people's life reflected in the works, you can find some art images and stereotypes of behavior, characteristic of the characters. The interpretation of various phenomena and processes through reading the works of art provides an opportunity for the young generation to comprehend a deep and objective reproduction of the development of artistic thinking and scientific and critical thinking of a particular period.

At the same time, the influence of social and artistic processes in the history of literature was accompanied by creation of not only the character of a new hero, but also a new type of writers. In the twentieth century an example of Ukrainian literature traditions development can be represented by K. Gordienko's literary works, which depict the reconstruction of the village, the destruction and devastation of traditional grain production and the introduction of a new system of collective farming. The author depicts the relationship of the characters at different times, provides their psychological portrays, and says about their love of home country, defending the rights and honor of every citizen. We believe that the study of the creative Chronicles of a Ukrainian writer will allow one to build and develop respect for the mother language and the people.

K. Gordienko, being a Ukrainian Soviet writer and relying on the traditions of Ukrainian literature, depicts the dramatic world of a man, who was ontologically rooted into life. In his works he tries to show the reconciliation of a man with himself, the drama of the past life. The writer sought not only to be faithful to the traditions of Ukrainian classical literature, but also to overcome the canons of the forcedly planted socialist realism. Characters, feelings, pictures of nature, experiences, emotional images, events, symbols, etc. - this is the arsenal which K. Gordienko used to describe a real picture of the world of those time reality. K. Gordienko's aesthetic position is characterized by adherence to principles, prudence of positions, and proof in solving historically significant problems raised by him. Today the heritage of the writer still remains relevant. The historical and literary concept of Gordienko-prose writer is connected with the principles of psychology, and the basis of his methodological approaches and achievements lies in understanding of social conditioning, the interpretation of the work from the standpoint of the historical document of the era.

Reading K. Gordienko's literature works, we should focus our attention on the context and realism of the pictures reproduced by the author. The artistic and cultural phenomenon of the writer's creative work lies in the true disclosure of the characters' psychology taken from the very life. At the level of life philosophy $\mathrm{K}$. Gordienko comprehended a new theme, through which he represented new images of contemporary reality, which remain relevant in our times. Synthesizing the techniques and means of reality artistic reproduction, the writer clearly reveals the balance of social forces to the reader, the major social conflicts of literary works; he shows the tempers and the mentality of social forces through his background characters, their actions and language. 
It should be noted that civic competence requires the participation in socially useful activities; respect for human rights and the exploits of people who fought for peaceful sky for themselves and their descendants; promotion and defending their own positions. In this aspect, reading the trilogy "Buymyr" by $\mathrm{K}$. Gordienko, it is possible to note such positive characteristics of the characters, as responsibility, patriotism, tolerance and respect for others. In his works, the writer often refers to the readers in order to draw attention to the difficulties a common man faces. Children were suffering in grief when losing their relatives and being in despair starting their independent way of life. Accordingly, one should focus on the fact that the respect for each person who is a member of the society, is a great virtue of any citizen.

In K. Gordienko's works we can see new characters having strong and courageous tempers. Not less important for the writer's works is the revealing of main characters' tempers and presentation of various conflicts in the texts. The writer often focuses our attention on topical issues that emerge in the pages of works of art, presenting mainly the peasants and their life troubles. The most significant problems which are described in the prose works by writer are: dissatisfaction with the peasant's poor situation ("Workers", "Buymyr", "She was reaping the other's field"); unemployment ("Workers", "A girl under an apple tree"); the life of rural mercenaries who had no other destiny ("Ostap Tur family", "She was reaping the other's field"); condemnation of divorce and constant servitude ("Ostap Tur family", "A girl under an apple tree", "Workers"); exaltation of the dignity of an ordinary person, regardless of its position in society ("Ostap Tur family", "She was reaping the other's field", "Buymyr"); social inequality ("She was reaping the other's field", "Workers", "A girl under an apple tree"); sad fate of talented people from the ("Ostap Tur family").

K. Gordienko repeatedly confirmed the idea that he was searching the ways to expose the negative defects of a society. He also was an expression of simple peasantry's mood. The author focused greatly his attention on psychological conflicts, which, for the most part, appeared inside the family, and were determined by deep penetration into a person's inner world.

During the times, reflected in the literary works by K. Gordienko, the theme of hunger was raised. People were constantly looking for food, at least for their children and the elderly: "It was raining the hungry people of Kharkiv with knots around their shoulders were wandering along the bogged roads, cold winds were blottering their clothes... The weak were standing in the middle of the field, in the middle of the world, they were devious and doomed ... Some were scattering around the stubble, raking off the piles of the icy ground with their frozen fingers, before covered by snow, and picking up the mice caches..." [2, p. 78]. People often felt hunger, as evidenced by the following lines: "She took a piece of bread in her hands and started shaking ..." [2, p. 59]. When thinking about the problems of the reality described in an artistic way, you start accepting the present differently, especially the period of the Holodomor of 1933.

The novel trilogy by K. Gordienko "Buymyr" reveals the characters' psychology in the background of the post-reform era and tragic events of the early twentieth century with the help of artistic word. It can be considered the vertex of writer's literature works, whose pages reveal the essence of a human in difficult times for the country. Here one can find the domestic and psychological, civil and patriotic issues that people faced those times.
It should be noted that it is possible to follow the life and creative destiny of the majority of Ukrainian writers of the twentieth century by K. Gordienko's example. At the same time, the author's artistic style and his worldview remain sharply individual, inherent only to him. In K. Gordienko's works there is an artistic perfection and vitality of the image of socio-economic and moralpsychological relations between people. It is hardly possible to compare the richness of socially significant realities and details taken from the real peasant everyday life with other literary works devoted to the same subject [11, p. 3].

Of course, reading literary texts will allow you to plunge into the plot, to form your own thoughts and civic stance. In order to increase the effectiveness of these activities, we propose the use of information and communication technologies, namely, the electronic tools for educational assignment entitled "Kostya Gordienko's literary contribution: the artistic and cultural phenomenon of the twentieth century". The computer program is intended to provide independent work of students of higher educational institutions when studying Ukrainian literature. It was registered by the State Service of Intellectual Property of Ukraine and certified of copyright "Kostya Gordienko's literary contribution: the artistic and cultural phenomenon of the twentieth century" (the author: T. Sharova, certificate no. 53673 dated February 14, 2014).

The electronic tool for educational purpose "Kostya Gordienko's literary contribution: the artistic and cultural phenomenon of the twentieth century" covers the important issues of teaching in high school a special course on the history of Ukrainian literature of the twentieth century, the main purpose of which is to highlight various figures in the context of the post-reform period. The content of electronic tool for educational purposes provides gaining knowledge about the theoretical and methodological foundations of Ukrainian prose in 20-60-ies of the twentieth century. It draws maximum attention to the literary works of $\mathrm{K}$. Gordienko as a representative of the older generation of writers, the founder of the Soviet prose, whose main subject is the life of the Ukrainian village of the twentieth century. There are more detailed data about this electronic tool for educational purposes which one can find in a tutorial [7].

Close proximity to the life of rural workers and human nature knowledge are the defining features of K. Gordienko's literary contribution. The specific organization of the writer's literary works determines the set of the following typological characteristics: the type of genre, the character of the thematic focus, the form of communication strategies, the principles of compositional organization and distinctiveness of speech processing.

Consequently, civil competence involves the active, conscious, and responsible attitude to social and civic processes directed at the development of the state. Developing civic culture through the art of the word can foster a true patriot of Ukraine, which is currently extremely important and necessary.

Conclusions. As a result of the complex analysis of K. Gordienko's works, we have identified the following means of word art for the formation of civic competence: studying the works of the Ukrainian writers of the twentieth century; reading of artistic texts; watching videos with patriotic direction; the research of the writer's epistolary; the study of poetry of artistic works.

When studying K. Gordienko's works in the literary context of artistic and aesthetic searches of the national literature 
of the 20th century, one can determine his national-patriotic views, raise respect and honesty, responsibility and courage, kindness and tolerance in contemporary youth. Therefore it will definitely allow to form one's civic competence as a qualitative feature of a true citizen of Ukraine.

In order to improve the process of forming a civic competence, it is promising to develop a didactic supplement that takes into account modern educational trends, for example, the use of the worked out electronic teaching aids that includes theoretical material, artwork, epistolary, photogallery, and video materials about K. Gordienko.

\section{References:}

1. Барау О.Ф., Смирнова М.О. Формування громадянської компетентності учнів засобами інформаційно-комунікаційних технологій. Інформачійні технології $і$ засоби навчання. 2013. Т. 38. № 6. C. $207-216$

2. Гордієнко К. Буймир: роман. Київ : Дніпро, 1972. 277 с.

3. Компетентнісний підхід у сучасній освіті: світовий досвід та українські перспективи: Бібліотека з освітньої політики / під заг. ред. О.В. Овчарук. Київ : «К.І.С.», 2004. 112 с.

4. Марченко В. Формування професійного іміджу сучасного вчителя. Наука і освіта. 2016. № 1. С. 120-125.

5. Панченко В. Нарис про автора «Буймир». Прапор. 1988. № 7. C. $159-162$.

6. Смагіна Т. Громадянська компетентність у контексті особистісного виміру. Вісник Житомирського державного університету імені Івана Франка. 2005. № 25. С. 229-231.

7. Шаров С.В., Шарова Т.М. Методологічні аспекти комп'ютерної підтримки самостійної роботи студентів-філологів: навч.-метод. посіб. / [2-ге видання доп. і перероб.] ; [передмова проф. І.Л. Михайлина]. Харків : Федорко, 2014. 200 с.

8. Шахрай В. Громадянська компетентність особистості як проблема сучасного суспільства. Украӥнський соиіум. 2008. № 2. С. 123- 34.

9. Шестопалюк О. Громадянська освіта як фактор формування громадянських компетентностей сучасної молоді. Рідна школа. 2010. № 3. C. 33-35.

10. Głowinski M., Okopien-Sławinska A., Sławinski J. Zarys teorii literatury. Wyd. 3. Warszawa: Panstwowe zakłady Wydawnictw Szkolnych, 1972. 544 p.

11. Ivanenko V. Original master of prose. News from Ukraine. № 50. 1974. P. 3.

12. Pang V., Gay G., Stanley W. Expanding conceptions of community and civic competence for a multicultural society. Theory \& Research in Social Education. 1995. T. 23. № 4. P. 302-331.

13. Prasanth J. Methods Of Teaching Civics. Discovery Publishing House. 2004. 280 p.

14. Schwartz J., Barone D. Assessing Civil Competence in the Elderly. Journal of Forensic Sciences. Vol. 37. № 3. 1992. P. 938-941.
Шарова Т. М., Шарова С. В., Карначова С. М. Формування громадянської компетентності засобами мистецтва слова (на прикладі творчості К. Гордіснка)

Анотація. Наразі спостерігається посилення інтересу до громадянської освіти, що пояснюється значними суспільними змінами у країні та інтеграцією України в європейський простір. Громадянська компетентність $\epsilon$ важливою умовою існування інтеркультурного та демократичного суспільства, в якому кожний громадянин активно виказує своє ставлення до різноманітних соціальних, політичних та національних процесів сьогодення. Одним із перспективних та дієвих засобів формування громадянської компетентності $\epsilon$ вивчення творів мистецтва та літератури, що надасть змогу людині навчитися аналізувати, порівнювати, співставляти образи, об'єкти та явища, формувати власну думку та активну громадянську позицію. Метою статті $є$ характеристика засобів мистецтва слова для формування громадянської компетентності на прикладі вивчення художніх творів К. Гордієнка, повідомлення про розробку та використання електронного засобу навчального призначення 3 метою кращого опанування творчістю митця. Для реалізації поставленої мети були використані методи аналізу, синтезу та систематизації, що дозволили визначити місце та роль доробку К. Гордієнка в історико-літературному процесі; для окреслення авторського бачення світу було застосовано біографічний метод; дослідження психологічних зрушень, відображених у поведінці та переживаннях головних героїв письменника, потребували звернення до прийомів дослідження психологізму; структурно-типологічний метод використовувався для аналізу та порівняння художніх текстів автора; системний підхід до розгляду творчої спадщини митця дав змогу актуалізувати системотворчі чинники його поетики. Було виявлено, що громадянська компетентність людини передбачає активне, свідоме та відповідальне ставлення до суспільних та громадянських процесів, спрямованих на розвиток держави. Розвиваючи громадянську культуру засобами мистецтва слова, можна виховати справжнього патріота України, що наразі вкрай актуально та необхідно. Комплексний аналіз творчого доробку письменника дав змогу з'ясувати роль і місце митця та його творів у літературному контексті художньо-естетичних пошуків вітчизняної літератури XX ст. та визначити його національно-патріотичні погляди. Із метою підвищення якості процесу формування громадянської культури був розроблений електронний засіб навчального призначення, який містить теоретичний матеріал, художні твори, епістолярій, фотогалерею, відеоматеріали про К. Гордієнка.

Ключові слова: громадянська компетентність, патріотизм, мистецтво слова, художня література, електронні засоби навчання. 